\title{
Characterization of the Extracellular Bactericidal Factors of Rat Alveolar Lining Material
}

\author{
J. Donald Coonrod, Robert L. Lester, and Li Chi Hsu \\ Section of Infectious Diseases, Department of Medicine \\ and Department of Biochemistry, Veterans Administration \\ Hospital and University of Kentucky Medical Center, \\ Lexington, Kentucky 40536
}

bstract. The surfactant fraction $(55,000-g$ pellet) of leukocyte-free rat bronchoalveolar lavage fluid contains factors that rapidly kill and lyse pneumococci. These factors were purified and identified biochemically by using a quantitative bactericidal test to monitor fractionation procedures. $91 \%$ of the antipneumococcal activity of rat surfactant was recovered in chloroform after extraction of rat surfactant with chloroform-methanol (Bligh-Dyer procedure). After chromatography on silicic acid with chloroform, acetone, and methanol, all detectable antibacterial activity $(\sim 80 \%$ of the initial activity) eluted with the neutral lipids in chloroform. When rechromatographed on silicic acid with hexane, hexane-chloroform, and chloroform, the antibacterial activity eluted with FFA. Thin-layer chromatography (TLC) established that the antibacterial activity was confined to the FFA fraction. Gas-liquid chromatography showed that the fatty acid fraction contained a mixture of long-chain FFA $\left(C_{12}\right.$ to $\left.C_{22}\right)$ of which $66.7 \%$ were saturated and $32.4 \%$ were unsaturated. The quantity of TLC-purified FFA needed to kill $50 \%$ of $10^{8}$ pneumococci under standardized conditions (one bactericidal unit) was $10.6 \pm 0.5 \mu \mathrm{g}$. Purified FFA acted as detergents, causing release of $\left[{ }^{3} \mathrm{H}\right]$ choline from pneumococcal cell walls and increased bacterial cell membrane permeability, evidenced by rapid unloading of $3-O-\left[{ }^{3} \mathrm{H}\right]$ methyl-Dglucose. FFA acting as detergents appear to account for the bactericidal and bacteriolytic activity of rat pulmonary surfactant for pneumococci.

\section{Introduction}

Studies of the mechanism of bacterial killing in the pulmonary alveoli have been carried out mainly with staphylococci with

Received for publication 31 January 1984 and in revised form 30 April 1984.

The Journal of Clinical Investigation, Inc.

Volume 74, October 1984, 1269-1279 standard histologic techniques, and the results indicate that staphylococci in the alveoli are killed predominantly by macrophages (1-4). These findings notwithstanding, alveolar macrophages often show poor chemotactic and phagocytic ability compared with peritoneal macrophages (5-7) and have weak intracellular killing activity in vitro $(8,9)$. Recently, Nugent and Pesanti (10) monitored intraalveolar killing of staphylococci by use of a bronchoalveolar lavage technique, rather than by microscopic examination of fixed tissue sections, and obtained evidence that inhaled staphylococci are killed mainly outside alveolar macrophages. The reasons for the different results are not clear but presumably relate to the different sampling methods used. With nonstaphylococcal bacteria, it has been assumed that macrophages have a major role in pulmonary clearance, but this possibility has not been proven. We have demonstrated that three different serotypes of pneumococci with greatly different opsonic requirements and virulence in rats are killed intraalveolarly at essentially the same rate ( $\sim 50 \%$ in $30 \mathrm{~min}$ ), suggesting that alveolar killing of pneumococci does not require conventional opsonins (11). In a search for extracellular bactericidal factors for pneumocci, we demonstrated that the surfactant fraction $(55,000-g$ pellet $)$ of leukocyte-free lavage of rats and other animal species contain heat and trypsin resistant factors that are rapidly bactericidal and lytic for pneumococci in vitro (12). The present studies provide complete characterization of these extracellular bactericidal factors.

\section{Methods}

Solvents. Chloroform, methanol, acetone, hexane, and benzene (all high pressure liquid chromatography grade) were obtained from Fisher Scientific Co., Fair Lawn, NJ.

Animals. Male Sprague-Dawley rats (200 g or more) were obtained from Charles River Breeding Laboratories, Inc. (Wilmington, MA). Adult albino guinea pigs were obtained from Hilltop Laboratories (Scottsdale, PA). The animals were housed in filtered air units.

Bronchoalveolar lavage. Lavage was carried out in rats as described elsewhere (13). In brief, rats were killed with an overdose of anesthetic (fluothane) and the lungs were lavaged in situ. A tracheotomy was made with a 22-gauge needle and a plastic catheter was inserted and secured with a tie. $5 \mathrm{ml}$ of phosphate-buffered saline (PBS) (pH 7.4) was infused and withdrawn for two to three cycles. The PBS was 
composed of $8.5 \mathrm{~g} \mathrm{NaCl}, 0.2 \mathrm{~g} \mathrm{KCl}, 1.05 \mathrm{~g} \mathrm{Na}_{2} \mathrm{HPO}_{4}$, and $0.2 \mathrm{~g}$ $\mathrm{KH}_{2} \mathrm{PO}_{4}$ per liter. The fluid was chilled immediately in an ice bath and centrifuged at $160 \mathrm{~g}$ for $5 \mathrm{~min}$ to remove leukocytes. The surfactantcontaining fraction was prepared by centrifuging leukocyte-free fluid at $55,000 \mathrm{~g}$ for $20 \mathrm{~min}$ and removing the supernatant. Guinea pigs were killed and lavaged in the same manner as rats except $10 \mathrm{ml}$ of PBS was used for lung lavage. Dogs were anesthetized with intravenous sodium thiamylal and lavaged with PBS through a catheter wedged into a bronchus. Lipolysis was evaluated by addition of radiolabeled phospholipids to the infusion fluid followed by fractionation on silicic acid and silica gel to detect the release of FFA. The lipids added were L-alpha-dipalmitoyl-[dipalmitoyl-1 $-{ }^{14} \mathrm{C}$ ] phosphatidylcholine, with a specific activity of $112 \mathrm{mCi} / \mathrm{mmol}$ and $\mathrm{L}-1$-[palmitoyl-1$\left.{ }^{14} \mathrm{C}\right]$ lysopalmitoylphosphatidylcholine, with a specific activity of 55 $\mathrm{mCi} / \mathrm{mmol}$. Both were obtained from New England Nuclear (Boston, MA).

Bacteria. Type 25 Streptococcus pneumoniae was obtained from the American Type Culture Collection (ATCC 6325), Rockville, MD, passed monthly in mice, and stored in heat-inactivated rabbit serum at $4^{\circ} \mathrm{C}$. Pneumococci were grown to log phase in brain-heart infusion broth containing $7 \%$ heat-inactivated rabbit serum over 5-6 h and washed once in PBS before bactericidal tests.

Type 25 pneumococci with radiolabeled cell walls were prepared as described previously (12) using a chemically defined medium and tritiated choline. In brief, pneumococci were grown overnight in synthetic medium with $1 \mu \mathrm{Ci}$ of $\left.{ }^{3} \mathrm{H}\right]$ methyl choline chloride per ml (80.0 Ci/mmol sp act, Sigma Chemical Co., St. Louis, MO). The radiolabeled bacteria $\left(\geq 14,500 \mathrm{cpm} / 10^{7}\right.$ bacteria) were washed in PBS and used immediately. Release of label from cell walls was measured by centrifuging lipid-treated bacteria at $1,600 \mathrm{~g}$ for $20 \mathrm{~min}$ and taking up the pellets and the supernatant fluids separately in Aquasol-2 (New England Nuclear). Freed radiolabel in the experimental tubes was expressed as percentage of total $\mathrm{cpm}$ minus $\mathrm{cpm}$ for controls (bacteria in PBS alone).

Pneumococci were labeled internally with 3-O-[ $\left.{ }^{3} \mathrm{H}\right]$ methyl-D-glucose $(80.0 \mathrm{Ci} / \mathrm{mmol} \mathrm{sp}$ act, Sigma Chemical Co.) by incubating $1 \mu \mathrm{Ci}$ of tritiated 3-O-methyl-D-glucose in $0.1 \mathrm{ml}$ of $0.1 \mathrm{mM}$ unlabeled 3-Omethyl-D-glucose and $0.1 \mathrm{ml}$ of $10^{8}$ washed, log-phase bacteria in PBS for $30 \mathrm{~min}$ at $37^{\circ} \mathrm{C}$. After four washes in PBS, the bacteria in $0.1 \mathrm{ml}$ were incubated with $0.2 \mathrm{ml}$ of lipid-containing sample at $37^{\circ} \mathrm{C}$ and the radioactivity released was determined by differential centrifugation and counting in Aquasol 2.

Bactericidal test. The bactericidal test was performed by incubating washed log-phase type 25 pneumococci $\left(\sim 10^{8}\right.$ in $0.1 \mathrm{ml}$ of PBS) with $0.2 \mathrm{ml}$ of lipid-containing sample or with PBS (control) for $60 \mathrm{~min}$ at $37^{\circ} \mathrm{C}$. Surviving bacteria in the control and test samples were then counted by plating 10 -fold dilutions of the reaction mixture on $5 \%$ sheep blood agar in $5 \% \mathrm{CO}_{2}$ overnight. The $50 \%$ bactericidal titer was determined with serial dilutions of test lipid prepared in chloroform, dried under nitrogen gas and dispersed in PBS with brief sonication. The percent of inoculum surviving at each dilution (in milliliters) was plotted on linear-log paper, and the dilution corresponding to $50 \%$ killing was interpolated graphically. The reciprocal of this dilution represented the $50 \%$ bacterial killing titer. A control tube to detect any antibacterial activity of solvent residues was included in most runs. Solvent controls were uniformly negative with high performance liquid chromatography-grade chemicals.

Lipid extraction. Lipids were extracted from fresh, pooled pulmonary surfactant with a modified Bligh-Dyer procedure (14). For each four rats in a pool the surfactant was suspended in $0.8 \mathrm{ml}$ of PBS and $3 \mathrm{ml}$ of chloroform-methanol (1:2) was added. The mixture was dispersed with sonication and chloroform $(1 \mathrm{ml})$ and water $(1 \mathrm{ml})$ were added with sonication after each addition. After centrifugation at $200 \mathrm{~g}$ for 5 min, the upper phase was discarded and the interphase was extracted again. The chloroform phases from the two extractions were pooled and dried with nitrogen gas. Total lipid weight was measured on a microbalance (Cahn Instruments, Inc., Cerritos, CA) and the lipid was dissolved in chloroform and stored at $-70^{\circ} \mathrm{C}$. Where indicated, heptadecanoic acid $\left(\mathrm{C}_{17: 0}\right)$ (Sigma Chemical $\mathrm{Co}$.) was added to crude lavage preparations before extraction for quantitation of FFA.

Column chromatography. Silicic acid chromatography was carried out using standard methods with a column (5:1, height/diameter)

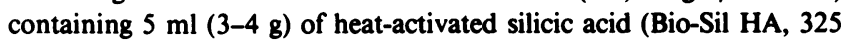
mesh, Bio-Rad Laboratories, Richmond, CA) and no more than 30 $\mathrm{mg}$ of lipid in $0.5 \mathrm{ml}$ of solvent per column. Columns were eluted successively with chloroform (10X columne volume), acetone (40X column volume), and methanol ( $10 \times$ column volume). Eluate fractions were collected, dried on a vacuum evaporator, and stored under chloroform. Controls to detect possible antibacterial effects of solvent residues were obtained with a silicic acid column without lipid. [1$\left.{ }^{14} \mathrm{C}\right]$ stearic acid $(40-60 \mathrm{mCi} / \mathrm{mmol}$ and $\mathrm{L}-1$-[palmitoyl-1$\left.{ }^{14} \mathrm{C}\right]$ lysophosphatidycholine palmitoyl, $55.0 \mathrm{mCi} / \mathrm{mmol}$ (New England Nuclear) were used to validate fractionation procedures.

In some experiments neutral lipids were eluted from a second 5$\mathrm{ml}$ silicic acid column with hexane (10X column volume); hexanechloroform, 10:1 (10X column volume); hexane-chloroform, 5:1 (10X column volume); and chloroform (10X column volume).

Thin-layer chromatography (TLC). ${ }^{1}$ Analytical $(250 \mu \mathrm{m}$ thick) and preparative $(1,000-\mu \mathrm{m}$ thick) plates of silica gel (Whatman Chemical Separations, Inc., Clifton, NJ) were used. The solvent used for analytical plates was petroleum ether, diethyl ether, and acetic acid (90:10:1). Standards included cholesterol, stearic acid, mono-, di-, and triglycerides, and sterol (Sigma Chemical Co.). Preparative plates for batch isolation of FFA were used with chloroform, methanol, and ammonium hydroxide $(66: 10: 2)$. Lipids were detected with $0.003 \%$ aqueous rhodamine. Plates were dried in a vacuum dessicator overnight and the area of the gel of interest was removed and eluted with chloroform, chloroformmethanol, 2:1, and chloroform-methanol, 1:2 (solvent volume/powder volume, 2:1). Eluates were pooled, dried under nitrogen, and the residues were stored in chloroform at $-70^{\circ} \mathrm{C}$.

Gas-liquid chromatography (GLC). Fatty acids were methylated as described by Metcalf et al. (15). In brief, lipid residues were dried under nitrogen gas, mixed with $1 \mathrm{ml}$ benzene and $1 \mathrm{ml}$ of $14 \%$ boron trifluoride in methanol (Sigma Chemical Co.) and heated for $30 \mathrm{~min}$ at $80^{\circ} \mathrm{C}$. Samples were cooled, mixed with $0.5 \mathrm{ml}$ water, and centrifuged at $200 \mathrm{~g}$ for $5 \mathrm{~min}$. The organic phase was separated, dried, and dissolved in hexane for GLC. Chromatography was carried out on a glass coil column $(1.8 \mathrm{~m} \times 2.6 \mathrm{~mm}$, i.d., Schimadzu GC-Mini 1 , Schimadzu Scientific Instruments, MD).

Fatty acids. Purified fatty acids for chromatographic standards and for studies of antibacterial activity were obtained from Sigma Chemical Co. except for docosatetraenoic acid and docosahexaenoic acid, which were purchased from Nu Chek Prep, Inc., (Elysian, MN).

\section{Results}

Quantitation of antipneumococcal activity. Titration of the number of type 25 pneumococci surviving incubation in rat

1. Abbreviations used in this paper: GLC, gas-liquid chromatography; TLC, thin-layer chromatography. 
bronchoalveolar lavage was used to monitor procedures for isolation and identification of antibacterial factors (Fig. 1). Titration was most sensitive in the region of $50 \%$ bacterial killing, where small changes in the concentration of antibacterial substances caused easily measurable changes in the number of bacteria killed. The reciprocal of the dilution of antibacterial substance (in milliliters) that produced $50 \%$ killing of pneumococci was taken as the bacterial killing titer and one unit of bacterial killing activity was defined as the activity which killed half of $10^{8}$ type 25 pneumococci under standardized conditions.

Antipneumococcal activity localized to surfactant lipids. It was demonstrated previously (12) that the antipneumococcal activity of leukocyte-free alveolar lavage fluid is located in the pellet obtained by centrifugation at $\geq 55,000 \mathrm{~g}$ (surfactantcontaining fraction) and is heat and trypsin resistant. These observations, which suggested the antibacterial factors are lipids, were substantiated by showing that most of the antibacterial activity can be extracted into chloroform. This finding was confirmed in the present work by extracting a preparation of pooled rat surfactant containing 16.0 units of antipneumococcal activity with chloroform-methanol (Bligh-Dyer procedure); 15.0 units (90.9\% of the total) were recovered in chloroform and 1.5 units remained in aqueous-methanol. Extraction of the antibacterial factors from the surfactant pellet into chloroform eliminated the problem of loss of antipneumococcal activity noted previously with rat surfactant stored in aqueous media. The antibacterial activity of the extracted surfactant lipids stored at $-70^{\circ} \mathrm{C}$ in chloroform was stable indefinitely.

Identification of antibacterial lipids of surfactant. The pro-

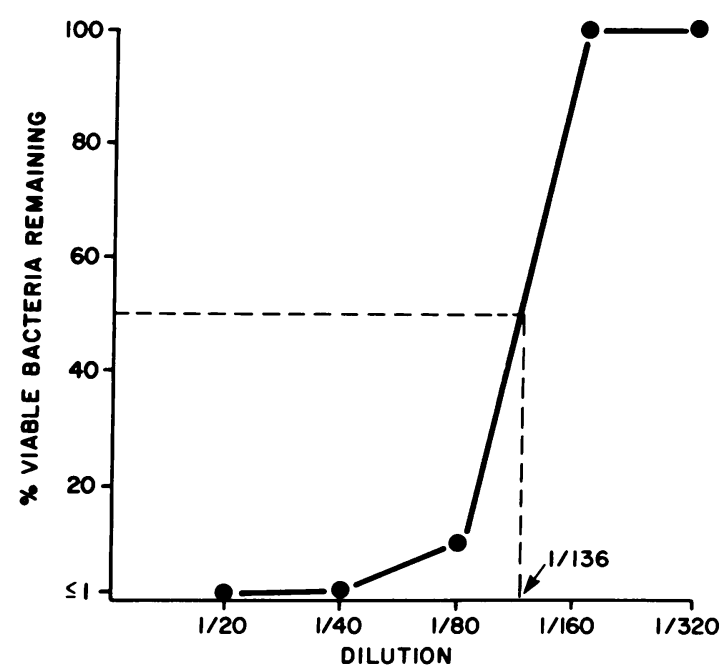

Figure 1. Titration of pneumococcal killing activity of rat bronchoalveolar lavage fluid. Dilutions of pooled, leukocyte-free lavage fluid were incubated $60 \mathrm{~min}$ at $37^{\circ} \mathrm{C}$ in $0.3 \mathrm{ml}$ with $10^{8}$ washed, log-phase type 25 pneumococci. The dilution required to kill $50 \%$ of the pneumococci was $1 / 136$; the undiluted material thus contained 136 bactericidal units.

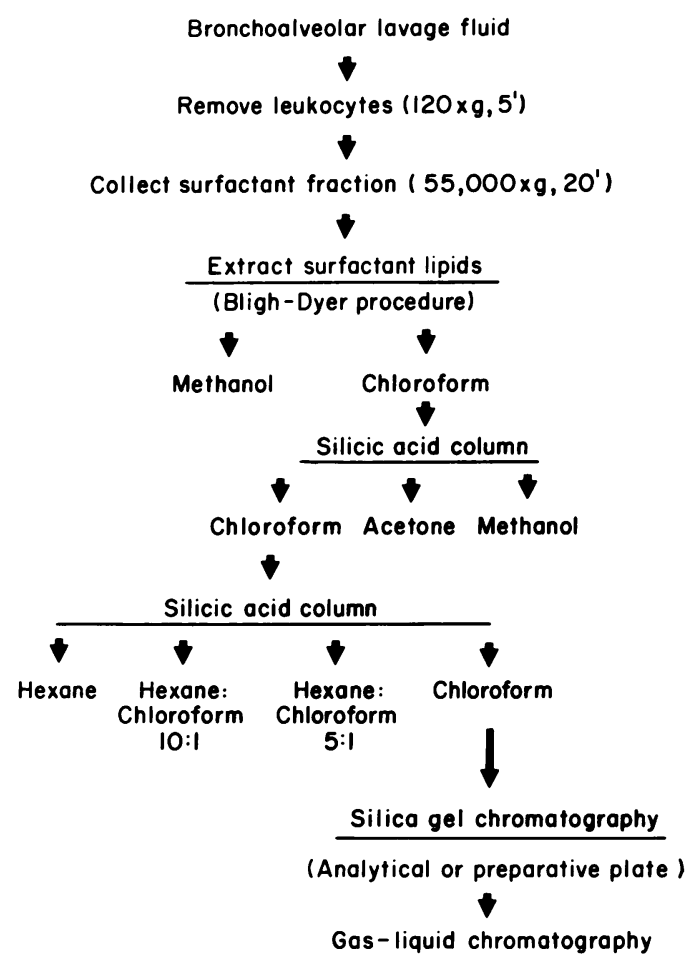

Figure 2. Protocol for isolation of antibacterial factors in rat bronchoalveolar lavage.

tocol indicated in Fig. 2 was followed in isolating antibacterial factors from rat lavage. Surfactant lipids that had been extracted in chloroform from leukocyte-free lavage fluid were weighed, fractionated on a silicic acid column that was eluted successively with chloroform, acetone, methanol, and the antibacterial titers of the fractions determined. As indicated in Table I, essentially all of the recoverable antibacterial activity $(\sim 80 \%$ of the starting activity) eluted from silicic acid in chloroform with little or no antibacterial activity in acetone or methanol. The chloroform fraction contained neutral lipids, as verified by elution of a $\left[{ }^{14} \mathrm{C}\right]$ stearate tracer (Table I). Lysophospholipids (i.e., $\left[{ }^{14} \mathrm{C}\right]$ lysophosphatidylcholine), also candidate substances for the antibacterial activity, eluted in methanol. These results indicated that neutral lipids rather than lysophospholipids were the source of antibacterial activity.

The neutral lipids from the first silicic acid column were purified further on a second silicic acid column by elution with hexane, hexane and chloroform combinations, or chloroform alone. Results (Table I) indicated that the antibacterial activity eluted predominantly in chloroform, as did $\left[{ }^{14} \mathrm{C}\right]$ stearate. Aliquots of chloroform eluates from the second silic acid column were analyzed with TLC on silica gels, by using a solvent of petroleum ether, diethyl ether, and acetic acid (90:10:1). Rhodamine-treated plates showed two spots, corresponding to the standards for cholesterol esters and FFA in the control lanes. Slices were prepared, washed thoroughly 
Table I. Fractionation of Antipneumococcal Activity of Rat Lavage

\begin{tabular}{|c|c|c|c|c|c|c|}
\hline \multirow[b]{2}{*}{ Preparation } & \multicolumn{4}{|c|}{ Lung lavage pools (Units of bactericidal activity)* } & \multicolumn{2}{|c|}{ Tracer (\% of total cpm) } \\
\hline & 1 & 2 & 3 & 4 & {$\left[{ }^{14} \mathrm{C}\right]$-stearate } & {$\left[{ }^{14} \mathrm{C}\right]$ lysophosphatidyl choline } \\
\hline Surfactant lipid extractł & 20.0 & 70.8 & - & - & 100.0 & 100.0 \\
\hline \multicolumn{7}{|l|}{ First silicic acid column } \\
\hline $\mathrm{CHCl}_{3}$ & 15.8 & 60.0 & 55.4 & 90.3 & 86.9 & 0.2 \\
\hline Acetone & $<0.3$ & $<0.3$ & $<0.3$ & - & 2.3 & 0.4 \\
\hline Methanol & $<0.3$ & $<0.3$ & $<0.3$ & - & 3.5 & 89.4 \\
\hline \multicolumn{7}{|l|}{ Second silicic } \\
\hline Hexane & - & $<0.3$ & $<0.3$ & - & 0.3 & - \\
\hline Hexane: $\mathrm{CHCl}_{3}(10: 1)$ & - & $<0.3$ & $<0.3$ & - & 0.0 & - \\
\hline Hexane: $\mathrm{CHCl}_{3}(5: 1)$ & - & 4.0 & $<0.3$ & - & 0.2 & - \\
\hline $\mathrm{CHCl}_{3}$ & - & 59.0 & 58.0 & 70.0 & 85.2 & - \\
\hline \multicolumn{7}{|l|}{$\begin{array}{l}\text { TLC (slices from } \\
\text { markers) }\end{array}$} \\
\hline Stearic acid & - & 55.0 & 60.0 & 65.0 & - & - \\
\hline Monoglyceride & - & $<0.3$ & $<0.3$ & - & - & - \\
\hline Cholesterol & - & $<0.3$ & $<0.3$ & - & - & - \\
\hline Tripalmitin & - & $<0.3$ & $<0.3$ & - & - & - \\
\hline Dipalmitin & - & $<0.3$ & $<0.3$ & - & - & - \\
\hline Cholesterol stearate & - & $<0.3$ & $<0.3$ & - & - & - \\
\hline
\end{tabular}

* Reciprocal of dilution that killed $50 \%$ of pneumococci times volume in milliliters of the undiluted preparation. $¥$ Extracted by Bligh-Dyer procedure. Pools prepared with $9-20$ rats.

with chloroform and methanol to recover the separated lipids, and the fractions tested for antipneumococcal activity. As indicated in Table I, the antibacterial activity was confined to the fraction corresponding to FFA. Controls to detect toxic effects of organic solvent residues on pneumococci were included throughout the procedure and were consistently negative. These data established that it was FFA in surfactant lipids that accounted for the antibacterial activity of rat bronchoalveolar lavage.

Quantitation of FFA in rat lavage. FFA in rat surfactant were identified and quantitated with GLC. Surfactant lipid was extracted into chloroform from leukocyte-free lavage fluid, weighed, and a known amount of heptadecanoic acid $\left(\mathrm{C}_{17: 0}\right)$ added. The neutral lipids were separated by elution with chloroform on silicic acid, and FFA were separated on preparative silica gel plates using chloroform, methanol, and ammonium hydroxide $(66: 10: 2)$. FFA were eluted from the TLC plates and methylated for GLC. The results (Table II) showed that there were 14 FFA with chain lengths of 12-22 carbons in the FFA fraction from TLC plates. Saturated FFA predominated (about two-thirds of the mixture), and a variety of unsaturated FFA comprised the remainder. FFA made up an average of $13.2 \%$ of the total surfactant lipid by weight.

The FFA mixtures from the TLC plates were tested for bactericidal activity and the quantity of FFA equivalent to one unit of bactericidal activity was very similar in different runs $(10.6 \pm 0.5 \mu \mathrm{g}$ FFA in the $0.3 \mathrm{ml}$ standard test mixture or $35.5 \pm 1.6 \mu \mathrm{g} \mathrm{FFA} / \mathrm{ml}$ ) (Table II).

Studies of lipolysis during lavage. To determine if FFA were released from surfactant lipids during lavage, dipalmitoyl phosphatidylcholine labeled with ${ }^{14} \mathrm{C}$ in both palmitate residues or palmitoyl lysophosphatidylcholine labeled with ${ }^{14} \mathrm{C}$ in the palmitate residue were added to the infusion fluid for lavage (PBS with $40 \mathrm{mM} \mathrm{Na} \mathrm{CO}_{3}, \mathrm{pH}$ 7.4). In the first experiment, $2.0 \mu \mathrm{Ci}$ of labeled dipalmitoyl phosphatidylcholine were mixed with $100 \mu \mathrm{g}$ of the unlabeled phospholipid and dispersed in infusion fluid. Lavage fluids from two rats were pooled and incubated at room temperature for $30 \mathrm{~min}$. The leukocytes were removed and the lipids in the supernatant were fractionated as usual. The leukocyte fraction contained 3.2\% (693 $\mathrm{cpm})$ of the recovered label with $96.8 \%(20,963 \mathrm{cpm})$ remaining in the supernatant. The surfactant-containing pellet from the leukocyte-free fluid had $10,719 \mathrm{cpm}(49.5 \%$ of the total cpm) and $91.0 \%$ of these counts were extracted into chloroform by the Bligh-Dyer procedure. During fractionation on silicic acid all detectable cpm above background $(8,813 \mathrm{cpm})$ eluted with methanol. Neither the chloroform nor acetone fractions contained detectable radiolabeled lipid. Thus, there was no evidence 
Table II. Quantitation of Purified FFA in Rat Lung Lavage Fluid by GLC

\begin{tabular}{|c|c|c|c|c|c|}
\hline \multirow[b]{2}{*}{ FFA* } & & \multicolumn{3}{|c|}{ Lavage poolsł } & \multirow[b]{2}{*}{ Mean \pm SD } \\
\hline & & 2 & 3 & 5 & \\
\hline \multicolumn{6}{|l|}{$\begin{array}{l}\text { Identified by GLC } \\
\quad(\% \text { in mixture): }\end{array}$} \\
\hline Lauric & $C_{12: 0}$ & 0.2 & 0.0 & 0.0 & $0.1 \pm 0.1$ \\
\hline Myristic & $C_{14: 0}$ & 2.6 & 3.0 & 2.7 & $2.8 \pm 0.2$ \\
\hline Palmitic & $C_{16: 0}$ & 61.2 & 65.0 & 52.8 & $59.7 \pm 6.3$ \\
\hline Palmitoleic & $C_{16: 1}$ & 9.2 & 9.6 & 9.9 & $9.7 \pm 0.4$ \\
\hline Stearic & $\mathrm{C}_{18: 0}$ & 2.5 & 4.2 & 6.0 & $4.2 \pm 1.7$ \\
\hline Oleic & $C_{18: 1}$ & 7.8 & 8.2 & 9.8 & $8.6 \pm 1.1$ \\
\hline Linoleic & $C_{18: 2}$ & 8.0 & 7.1 & 10.3 & $8.5 \pm 1.6$ \\
\hline Linolenic & $C_{18: 3}$ & 0.3 & 0.0 & 0.6 & $0.3 \pm 0.2$ \\
\hline Homo- $\gamma$-linolenic & $\mathrm{C}_{20: 3}$ & 0.2 & 0.0 & 0.2 & $0.1 \pm 0.1$ \\
\hline Arachidonic & $C_{20: 4}$ & 4.7 & 2.5 & 3.5 & $3.6 \pm 1.1$ \\
\hline Eicosapentaenoic & $C_{20: 5}$ & 0.6 & 0.0 & 0.4 & $0.3 \pm 0.3$ \\
\hline Docosatetraenoic & $\mathrm{C}_{22: 4}$ & 0.4 & 0.0 & 0.2 & $0.2 \pm 0.2$ \\
\hline Docosapentaenoic & $C_{22: 5}$ & 0.6 & 0.0 & 0.3 & $0.3 \pm 0.3$ \\
\hline Docosahexaenoic & $\mathrm{C}_{22: 6}$ & 1.6 & 0.4 & 0.7 & $0.9 \pm 0.6$ \\
\hline Unidentified & & 0.1 & 0.0 & 2.6 & $0.9 \pm 1.5$ \\
\hline \% Saturated & & 66.5 & 72.2 & 61.5 & $66.7 \pm 5.3$ \\
\hline \% Unsaturated & & 33.4 & 27.8 & 35.9 & $32.4 \pm 4.1$ \\
\hline FFA total ( $\mu g$ /animal) & & 706 & 68 & 228 & $334 \pm 332$ \\
\hline Lipid total ( $\mu g /$ animal) & & 3715 & 839 & 1809 & $2121 \pm 839$ \\
\hline FFA (as \% total lipid) & & 19.0 & 8.1 & 12.6 & $13.2 \pm 5.5$ \\
\hline \multicolumn{6}{|c|}{$\begin{array}{l}\text { FFA that killed } 50 \% \text { of } 10^{8} \\
\text { pneumococci (one } \\
\text { bactericidal unit): }\end{array}$} \\
\hline$\mu \mathrm{g}$ in test & & 10.0 & 10.2 & 11.6 & $10.6 \pm 0.5$ \\
\hline$\mu \mathrm{g} / \mathrm{ml}$ & & 33.3 & 34.0 & 38.6 & $35.3 \pm 1.6$ \\
\hline
\end{tabular}

* Lipids in lung lavage fluid were extracted by the Bligh-Dyer procedure and purified by silicic acid and thin layer (silica gel) chromatography before GLC. ¥ Bronchoalveolar lavage fluid obtained from 9-20 animals for each pool.

of lipolysis. In a second experiment $1.0 \mu \mathrm{Ci}$ of ${ }^{14} \mathrm{C}$-labeled palmitoyl lysophosphatidylcholine in $100 \mu \mathrm{g}$ of the unlabeled lysolipid was dispersed in infusion fluid and each of two rats was lavaged. The fluids were pooled, incubated at room temperature for $30 \mathrm{~min}$, and the leukocytes were separated. The whole lavage contained $7,947 \mathrm{cpm}(100 \%)$ with $3.6 \%$ of the total separating with the leukocytes and $43.3 \%$ of the cpm separating with the surfactant-containing pellet. In the BlighDyer extraction, $90.0 \%$ of the $\mathrm{cpm}$ in the surfactant fraction were extracted into chloroform. On silicic acid fractionation, all detectable cpm above background eluted with methanol, indicating that no FFA were released from the lysolipid.

Antipneumococcal activity of pure FFA. To determine which FFA identified by GLC in rat surfactant were antibacterial, seven of the most abundant were tested alone and combined in proportions that simulated the natural material. Fatty acids were obtained commercially ( $\sim 98 \%$ purity), dispersed and serially diluted in chloroform, and dried with nitrogen gas. To conform to the conditions previously used with lavage, the lipid residues were redispersed as well as possible with sonication in $0.2 \mathrm{ml}$ PBS (saturated FFA did not disperse as well as unsaturated FFA). Washed, log-phase pneumococci $\left(10^{8}\right.$ in $0.1 \mathrm{ml}$ of PBS) were added, and the mixtures were incubated at $37^{\circ} \mathrm{C}$. The results (Fig. 3) indicated wide variability in the antibacterial activity of individual FFA. Saturated FFA (palmitic, stearic, and myristic acids) had little or no antipneumococcal activity $(400$ to $>3,200 \mu \mathrm{g} / \mathrm{ml}$ for $50 \%$ killing). The most highly unsaturated acid tested, arachidonic, had the most antipneumococcal activity (50\% killing at $8 \mu \mathrm{g} / \mathrm{ml}$. Other unsaturated FFA (linoleic, oleic, and palmitoleic) were intermediate in activity (50\% killing at $22-114 \mu \mathrm{g} / \mathrm{ml}$ ). A mixture of the seven FFA killed $50 \%$ of pneumococci at 79 $\mu \mathrm{g} / \mathrm{ml}$. This value was higher than the concentration of purified

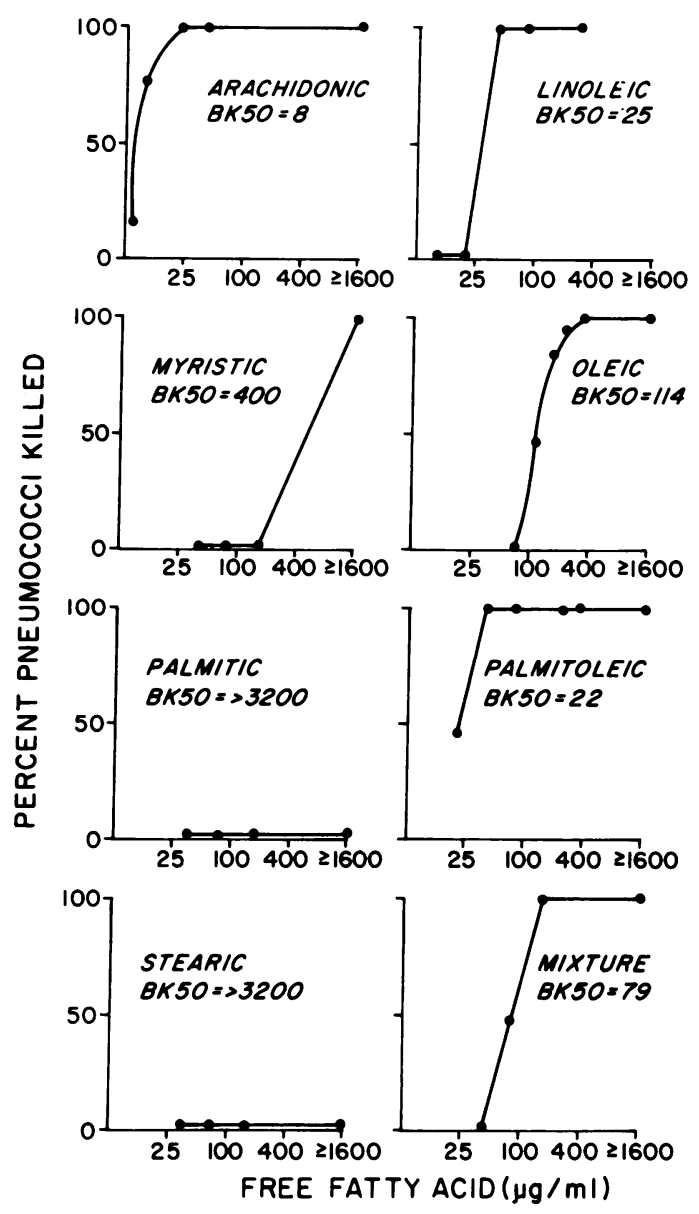

Figure 3. Titration of antipneumococcal activity of pure FFA. Pneumococci $\left(10^{8}\right)$ were incubated with the indicated FFA for $60 \mathrm{~min}$ at $37^{\circ} \mathrm{C}$ and surviving bacteria were cultured on blood agar. The quantity of FFA required to kill $50 \%$ of the bacteria (BK50) is indicated in the panels in micrograms of fatty acid per milliliter. The FFA mixture was composed of the seven FFA indicated in the figure in the proportions that they occur in rat pulmonary surfactant. Points represent means of two or three experiments. 
surfactant FFA required for $50 \%$ killing $(35.3 \mu \mathrm{g} / \mathrm{ml}$, Table II), indicating slightly more activity in the natural material.

To test the effect of divalent cations on pneumococcal killing by FFA, $10^{8}$ type 25 pneumococci were incubated with the "simulated" FFA mixture in Hank's balanced salt solution with or without calcium or magnesium (pH 7.0) (Gibco Laboratories, Grand Island, NY). The number of surviving bacteria after $45 \mathrm{~min}$ at $37^{\circ} \mathrm{C}$ with $37.5 \mu \mathrm{g} \mathrm{FFA} / \mathrm{ml}$ was $12 \%$ without divalent ions and $54 \%$ with divalent ions. At $75 \mu \mathrm{g}$ FFA/ml the figures were, respectively, 0 and $32 \%$. Thus, divalent ions inhibited FFA to some extent. The effect of $\mathrm{pH}$ was evaluated by testing pneumococcal killing in PBS at $\mathbf{p H}$ 6.9 vs 7.3. At $75 \mu \mathrm{gFA} / \mathrm{ml}$ survival at either $\mathrm{pH}$ was $<5 \%$. At $37.5 \mu \mathrm{g}$ FFA $/ \mathrm{ml}$ survival was $35 \%$ at $\mathrm{pH} 7.3$ and $52 \%$ at pH 6.9.

Table III. Release of $\left[{ }^{3} \mathrm{H}\right]$ Choline from Cell Walls of Viable Type 25 Pneumococci by Rat Surfactant Lipids*

\begin{tabular}{|c|c|c|}
\hline Fraction & Dilution & $\begin{array}{l}\text { \% }\left[{ }^{3} \mathrm{H}\right] \text { choline } \\
\text { released } \neq\end{array}$ \\
\hline \multicolumn{2}{|l|}{ Surfactant pellet (20-fold } & \\
\hline fluid) & Undiluted & $39 \pm 1$ \\
\hline \multicolumn{3}{|l|}{ 1st silicic acid column: } \\
\hline \multirow[t]{3}{*}{ Chloroform } & Undiluted & $41 \pm 3$ \\
\hline & $1 / 20$ & $34 \pm 3$ \\
\hline & $1 / 40$ & $16 \pm 2$ \\
\hline \multirow[t]{2}{*}{ Acetone } & Undiluted & 0 \\
\hline & $1 / 20$ & 0 \\
\hline \multirow[t]{2}{*}{ Methanol } & Undiluted & $2 \pm 1$ \\
\hline & $1 / 20$ & 0 \\
\hline \multicolumn{3}{|l|}{ 2nd silicic acid column: } \\
\hline \multirow[t]{3}{*}{ Hexane } & Undiluted & 0 \\
\hline & $1 / 20$ & $4 \pm 5$ \\
\hline & $1 / 40$ & $6 \pm 0$ \\
\hline \multirow[t]{3}{*}{ Hexane/chloroform, 5:1 } & Undiluted & $4 \pm 3$ \\
\hline & $1 / 20$ & $5 \pm 1$ \\
\hline & $1 / 40$ & 0 \\
\hline \multirow[t]{2}{*}{ Chloroform } & Undiluted & $41 \pm 1$ \\
\hline & $1 / 20$ & $35 \pm 4$ \\
\hline
\end{tabular}

* Pneumococci containing $\left[{ }^{3} \mathrm{H}\right]$ choline $\left(10^{8}\right.$ in $\left.0.1 \mathrm{ml} \mathrm{PBS}\right)$ were incubated for $60 \mathrm{~min}$ at $37^{\circ} \mathrm{C}$ with $0.2 \mathrm{ml}$ of the lipid fractions in PBS. Samples were centrifuged and the amount of $\left[{ }^{3} \mathrm{H}\right]$ choline remaining in the supernatant and pellet was measured with a scintillation counter.

‡\% Radiolabel released into supernatant in experimental samples minus that in PBS-treated controls. Controls were $\leq 13.5 \%$ of total cpm. Mean \pm SD of duplicates.
Actions of FFA on pneumococci. In previous work (12), killing of type 25 pneumococci by rat lavage was accompanied by bacteriolysis which was quantified by labeling pneumococci with $\left[{ }^{3} \mathrm{H}\right]$ choline and measuring release of the radiolabel from cell walls during incubation with lavage. $\left[{ }^{3} \mathrm{H}\right]$ choline release is dependent on normal levels of pneumococcal autolytic enzyme (murein hydrolase) $(12,16)$. In the present work, lipid fractions were dried under $\mathrm{N}_{2}$, dispersed in PBS and incubated at $37^{\circ} \mathrm{C}$ with pneumococci labeled with $\left[{ }^{3} \mathrm{H}\right]$ choline. The suspensions were centrifuged at $1,600 \mathrm{~g}$ for $20 \mathrm{~min}$ and the amount of radiolabel in supernatants and pellets was determined. Table III shows the bacteriolytic activity obtained with fractions of surfactant lipids eluted from silicic acid columns mainly in chloroform. The chloroform fraction from the second column was further fractionated by TLC where bacteriolytic activity was localized to the FFA fraction.

As indicated in Fig. 4, the release of cell wall $\left[{ }^{3} \mathrm{H}\right]$ choline by FFA in TLC purified from rat surfactant was similar quantitatively to results obtained with a pure fatty acid mixture composed of the seven most abundant FFA in surfactant.

Effect of FFA on pneumococcal cell membrane permeability. A previous observation (12) that rat lavage alters pneumococcal cell membrane permeability (as detected by unloading of

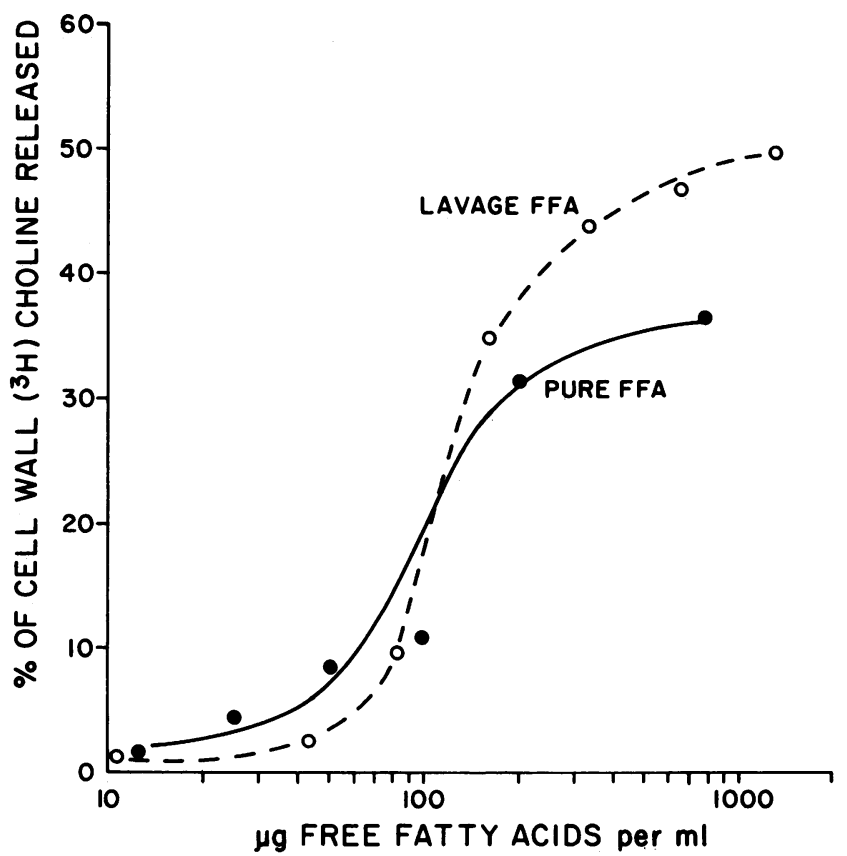

Figure 4. Quantitation of pneumococcal cell wall lysis by FFA. Pneumococci labeled with $\left[{ }^{3} \mathrm{H}\right]$ choline were incubated with FFA isolated from rat alveolar surfactant (broken line) by silicic acid and silica gel chromatography or with a pure FFA mixture (solid line) of the seven most abundant FFA present in rat surfactant. $\left[{ }^{3} \mathrm{H}\right]$ choline freed was measured by scintillation counting. Points are means of duplicate tubes in a single experiment. $\left[{ }^{3} \mathrm{H}\right]$ choline release by pneumococci in PBS with 9.9\% and this value has been subtracted. 
$\left[{ }^{3} \mathrm{H}\right]$ methyl-D-glucose) was confirmed in the present study. When $10^{8}$ viable pneumococci loaded with $\left[{ }^{3} \mathrm{H}\right]$ methyl-Dglucose were incubated with 20 -fold concentrated, pooled rat surfactant in $0.3 \mathrm{ml}$ of $\mathrm{PBS}, 40 \pm 4 \%$ of the radiolabel was released into the supernatant within $30 \mathrm{~min}$. Fig. 5 shows that a mixture of pure FFA mimicked this action, causing unloading of methyl-D-glucose at $30 \mathrm{~min}$ in the concentration range of $30-40 \mu \mathrm{g}$ of $\mathrm{FFA} / \mathrm{ml}$.

Antibacterial spectrum of FFA. The spectrum of antibacterial activity of a mixture of pure FFA stimulating rat lavage was determined. The results (Table IV) showed that FFA had doserelated antibacterial activity, which was greatest with pneumococci, group A and B streptococci, and unspeciated "respiratory" streptococci. The activity was less against group D streptococci and Staphylococcus aureus, and least with aerobic gram-negative bacilli (pseudomonas, enterobacter, serratia, and proteus). The data indicated that the spectrum of activity was greater with higher concentrations of FFA.

FFA in nonmurine surfactants. FFA in surfactant fractions of bronchoalveolar lavage fluids of dogs and guinea pigs were determined (Table V). FFA in these two species were similar. Both saturated and unsaturated FFA were detected with the former having a slight preponderance. As in rats (Table II) palmitic acid was the most abundant saturated FFA with lesser percentages of myristic and stearic acids also present. Guinea pig and dog lavage showed higher percentages of oleic acid and less arachidonic acid and higher unsaturated FFA than rat surfactant.

The amount of FFA in the surfactant preparations varied: mean FFA (expressed as percentage of total lipid) was less for guinea pigs $(0.97 \%)$ and dogs $(4.5 \%)$ than for rats $(13.2 \%$, Table II).

\section{Discussion}

The present studies demonstrate that bronchoalveolar lavage of several animal species contains antibacterial, long chain FFA. Antibacterial activity of lipid fractions extracted from rat pulmonary surfactant and purified by silicic acid and silica gel chromatography were monitored quantitatively by titration of antipneumococcal activity. Only the neutral lipid fraction

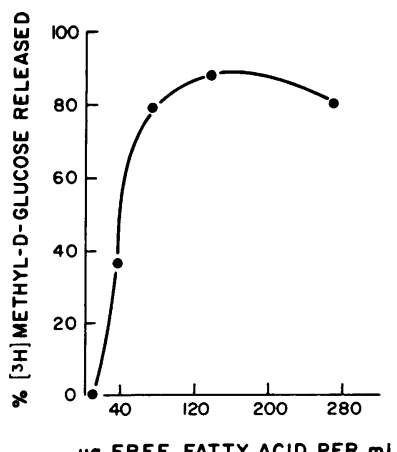

Figure 5. Release of $\left[{ }^{3} \mathrm{H}\right]$ methyl-Dglucose from pneumococci incubated for 30 min at $37^{\circ} \mathrm{C}$ with a pure FFA mixture. An autolysindefective pneumococcal transformant was used to prevent cell wall lysis during incubation. Means of duplicate tubes in a single experiment. The control (pneumococci in PBS) released $7.1 \%$ which value Hg FREE FATTY ACIO PER $\mathrm{ml}$ has been subtracted.
Table IV. Effect of a Mixture of Pure FFA on Viability of Various Bacteria*

\begin{tabular}{|c|c|c|}
\hline \multirow[b]{2}{*}{ Bacteria } & \multicolumn{2}{|c|}{ \% Bacteria surviving } \\
\hline & $75 \mu \mathrm{g} / \mathrm{ml}$ & $250 \mu \mathrm{g} / \mathrm{ml}$ \\
\hline & Mean $\pm S E \ddagger$ & $M e a n \pm S E \ddagger$ \\
\hline \multicolumn{3}{|l|}{ Pneumococci } \\
\hline Type 3 & $<1 \pm 0$ & $<1 \pm 0$ \\
\hline Type 25 & $<1 \pm 0$ & $<1 \pm 0$ \\
\hline \multicolumn{3}{|c|}{ Unspeciated respiratory streptococcus } \\
\hline ("alpha-streptococci") & $12 \pm 13$ & $<1 \pm 0$ \\
\hline \multicolumn{3}{|c|}{ Streptococcus pyrogenes (Lancefield } \\
\hline group A) & $<1 \pm 0$ & $<1 \pm 0$ \\
\hline S. agalactiae (group B) & $<1 \pm 0.2$ & $<1 \pm 0$ \\
\hline S. fecalis (group D) & $54 \pm 17$ & $13 \pm 13$ \\
\hline S. durans (group D) & $36 \pm 29$ & $<1 \pm 0$ \\
\hline S. bovis (group D) & $45 \pm 12$ & $<1 \pm 0.2$ \\
\hline \multicolumn{3}{|l|}{ Straphylococcus aureus } \\
\hline isolate 1 & $26 \pm 11$ & $3 \pm 4$ \\
\hline isolate 2 & $20 \pm 19$ & $<1 \pm 0$ \\
\hline isolate 3 & $77 \pm 30$ & $2 \pm 2$ \\
\hline Klebsiella pneumoniae & - & $91 \pm 0.5$ \\
\hline Enterobacter aerogenes & - & $68 \pm 8$ \\
\hline Serratia marcescens & - & $81 \pm 4$ \\
\hline Proteus vulgaris & - & $38 \pm 6$ \\
\hline
\end{tabular}

- A mixture of the nine most abundant FFA in rat surfactant in the proportions encountered naturally was dispersed by brief sonication in PBS and incubated in the indicated concentrations with $10^{8}$ washed log-phase bacteria for 90 min at $37^{\circ} \mathrm{C}$. Surviving bacteria were determined by culture overnight at $37^{\circ} \mathrm{C}$. ¥ Two to four experiments performed in duplicate for each organism.

showed antipneumococcal activity, and this activity was caused only by the FFA in the neutral lipids.

It was demonstrated that purified FFA from rat surfactant behaved as detergents, causing autolytic lysis of pneumococci and release of $\left[{ }^{3} \mathrm{H}\right]$ choline from pneumococcal cell walls. A mixture of pure, commercially obtained FFA was as effective as the FFA mixture in rat surfactant in breaking down pneumococcal cell walls. Like surfactant FFA (12), pure FFA also increased pneumococcal cell membrane permeability, as demonstrated by unloading of 3-O-[ $\left[{ }^{3} \mathrm{H}\right]$ methyl-D-glucose from an autolysin-defective pneumococcal transformant. Although lysophosphatides are present in mammalian surfactant (17$19)$ and can act as antibacterial detergents in vitro $(20,21)$, causing increased bacterial membrane permeability and autolytic lysis of pneumococci (12), the phospholipid fraction of rat surfactant had no antipneumococcal activity. FFA were the only antibacterial factors detected in rat surfactant that could account for the detergent effects on pneumococci that we have observed with crude rat lavage fluid.

Fatty acids are well-known antimicrobial substances with activity in vitro against gram-positive and gram-negative bacteria $(22-26)$, fungi $(27,28)$, and enveloped viruses, including influenza (29-31). FFA have been used widely as food perservatives. Lipids, and especially FFA, are believed to play an important role in the antimicrobial defenses of the skin (32- 
Table V. Quantitation of FFA in Bronchoalveolar Lavage Fluid of Nonmurine Species

\begin{tabular}{|c|c|c|c|c|c|c|c|}
\hline \multirow[b]{2}{*}{ FFA $^{*}$} & & \multicolumn{3}{|c|}{ Guinea pig lavageł } & \multicolumn{3}{|c|}{ Dog lavage§ } \\
\hline & & 1 & 2 & Mean & 1 & 2 & Mean \\
\hline \multicolumn{8}{|c|}{$\begin{array}{l}\text { Identified by GLC } \\
\text { (\% in mixture): }\end{array}$} \\
\hline Myristic & $C_{14: 0}$ & 0 & 5.0 & 2.5 & 10.0 & 4.3 & 7.1 \\
\hline Palmitic & $C_{16: 0}$ & 40.8 & 35.8 & 38.3 & 22.8 & 44.9 & 33.9 \\
\hline Palmitoleic & $C_{16: 1}$ & 0 & 5.4 & 2.7 & 7.4 & 8.1 & 7.8 \\
\hline Stearic & $C_{18: 0}$ & 11.4 & 16.1 & 13.8 & 14.0 & 8.8 & 11.4 \\
\hline Oleic & $\mathrm{C}_{18: 1}$ & 47.8 & 25.8 & 36.8 & 38.6 & 26.2 & 32.4 \\
\hline Linoleic & $\mathrm{C}_{18: 2}$ & 0 & 1.1 & 0.6 & 7.2 & 5.1 & 6.1 \\
\hline Linolenic & $\mathrm{C}_{18: 3}$ & 0 & 0 & 0 & 0 & 0 & 0 \\
\hline \multicolumn{8}{|c|}{ Arachidonic $\mathrm{C}_{20: 4}$ and } \\
\hline higher u & & 0 & 0 & 0 & $\mathbf{0}$ & 2.4 & 1.2 \\
\hline Unidentified & & 0 & 10.9 & 5.4 & 0 & 0.2 & 0.1 \\
\hline \% Saturated & & 52.2 & 56.9 & 54.5 & 46.8 & 58.0 & 52.4 \\
\hline \% Unsaturate & & 47.8 & 32.3 & 40.1 & 53.2 & 41.8 & 47.5 \\
\hline FFA total $(\mu g$ & & 3.0 & 140 & 71.5 & 500 & 830 & 665 \\
\hline Lipid total $(\mu$ & & 1,555 & 7,960 & 4,757 & 20,700 & 12,780 & 16,740 \\
\hline FFA $\%$ total 1 & & 0.2 & 1.75 & 0.97 & 2.4 & 6.5 & 4.5 \\
\hline
\end{tabular}

* Lipids in lung lavage fluid were extracted by the Bligh-Dyer procedure and purified by silicic acid and thin layer (silica gel) chromatography before GLC. $\ddagger$ Lavage from 9-12 animals for each pool. § Individual lavages (300-400 ml each).

35). Ricketts et al. (33), for example, demonstrated that skin lipids contain an appreciable quantity of oleic acid, and they correlated the sensitivity of staphylococci and streptococci to FFA in vitro with the rate of their disappearance from the skin. Aly et al. $(34,35)$ showed that staphylococci, streptococci, and candida rapidly decreased in number after being deposited on normal skin, whereas acetone-washed skin allowed greater persistence of the microorganisms. When skin surface acetone extracts were replaced on washed skin, the increased bacterial counts were not seen. Aly et al. $(34,35)$ also demonstrated a direct correlation between the degree of killing of experimentally applied staphylococci, streptococci, and candida and degree of inhibition in vitro by acetone extracts of the skin surface.

It has been suggested that FFA can affect the flora of the gastrointestinal tract. Polyunsaturated FFA and lysolecithin in the small intestine of pigs appear to prevent proliferation of orally administered Clostridium welchii (36). Human fecal lipids contain a mixture of long chain FFA $\left(C_{16: 0}, C_{18: 1}, C_{18: 2}\right.$, and $C_{220}$ ), which are bactericidal for gonococci (37), and rectal gonococcal isolates have been shown to be more resistant to fecal FFA than are cervical or urethral isolates, suggesting that there is selection of gonococci in vivo based on FFA sensitivity.

FFA have been identified in vaginal secretions (38) and human breast milk (39) where they may have a role as antistaphylococcal agents. Also, it has been shown that acellular supernatants of pus from experimental subcutaneous abscesses are bactericidal for staphylococci and this activity is caused by a mixture of long chain FFA and lysolecithin (40). Inasmuch as FFA have been found to play a significant role in host defenses of the skin and mucosal surfaces, their role in alveolar defenses warrants consideration.

The spectrum of antibacterial activity of FFA in vitro varies with chain length, the degree of unsaturation, the methods used to disperse the lipids, and other experimental variables (22-26, 41-44). In general, both gram-positive and gram-negative bacteria have an equal (and low) level of sensitivity to short chain $\left(\mathrm{C}_{10}\right.$ and shorter) FFA. Long chain FFA have greater antibacterial activity, particularly against certain gram-positive bacteria, possibly because the outer membrane of gram-negative bacteria tends to block penetration of FFA (45). The spectrum of antibacterial activity observed with pure FFA helps to explain the spectrum of antibacterial activity we observed with crude rat surfactant (12); the crude material is most active against certain gram-positive bacteria, such as pneumococci, and penicillin-sensitive streptococci and least active against aerobic gram-negative bacilli. In the present studies low concentrations (i.e., $75 \mu \mathrm{g} / \mathrm{ml}$ ) of pure FFA prepared to simulate the naturally occurring FFA mixture in rat lavage had essentially the same spectrum of activity as previously reported for crude rat lavage (12). Higher FFA concentrations $(250 \mu \mathrm{g} / \mathrm{ml})$, however, also had some activity against staphylococci and gram-negative bacilli. The spectrum of activity possible in vivo would obviously depend on the concentration of FFA in the alveoli. 
Although reported results have varied, unsaturated FFA appear more active than saturated FFA as antibacterial agents (24). This is particularly true for chain lengths of 18 or more carbons and for gram-negative organisms. Our results are consistent with this observation, but in vitro results cannot be readily extrapolated to the situation in vivo. Our original evaluation of bactericidal activity of lavage was carried out in an aqueous system (12) and aqueous conditions were maintained in the present study. Saturated FFA disperse less well than unsaturated FFA in water and this fact may have accounted for the results.

The mechanism(s) by which FFA kill gram-positive or gram-negative bacteria are not known in detail. Lysis of the pneumococcal cell wall by detergents, although visually impressive, is not necessary for pneumococcal killing (12). At suitable concentrations FFA can cause leakage and even lysis of bacterial cell membranes $(46,47)$ as well as various cellular metabolic effects, including inhibition of respiratory activity, effects on transportation of amino acids, and uncoupling of oxidative phosphorlization (48-50). Although our present and previous work suggests that FFA in rat surfactant alter pneumococcal cell membrane permeability, the exact mechanism of killing is not known.

Pulmonary lavage, as obtained in the present studies, contains both bronchial and alveolar secretions and either might contribute to the mixture of FFA isolated from the surfactant fraction of lavage. we demonstrated previously that gradient-purified lamaller bodies, which are lipid structures produced only by the type II alveolar epithelial cell (and thus solely of alveolar origin), display the same antipneumococcal activity as crude rat lavage (12). This fact suggests that the antibacterial activity in lavage comes from alveolar secretions. Also, mucus inactivates the antipneumococcal activity of lavage (12), which makes it unlikely that the antibacterial activity comes from the bronchial tree where mucus is abundant.

FFA have been demonstrated in varying amounts in surfactant obtained by lavage from dogs $(17,19)$ humans $(18)$, and in the present studies, rats and guinea pigs. Studies indicate that the quantity of FFA in normal human surfactant is 3\% of the total surfactant lipid (18). Published studies on dog surfactant show variable amounts of FFA, ranging from 1 to $7 \%$ of the total surfactant lipid weight; the corresponding figure in the present study $(4.5 \%)$ is in this range. The FFA in canine lavage identified by GLC in studies of Pfleger et al. (17) are very similar to the present results: palmitic acid $(43 \%$ of the total) and oleic acid (27\%) were the most abundant, with myristic $(1 \%)$, palmitoleic $(8 \%)$, stearic $(7 \%)$, linoleic $(5 \%)$, linolenic (2\%), and $\mathrm{C}_{20}$ and higher FFA (8\%) also present. The present study indicated that in comparison with dog lavage, rat lavage contained more FFA (mean, $13.2 \%$ of total surfactant lipid weight) and guinea pig contained less FFA (mean, $0.97 \%$ of total lipid). These results may explain our inability in earlier studies (12) to detect antipneumococcal activity with lavage from guinea pigs, whereas rat and canine lavage were active.
The amount of FFA detected with crude lavage in vitro varies even among different lavage preparations from animals of the same species, possibly due to varying contamination with mucus or proteins that can bind FFA. FFA are present in lipid extracts of supernatants of rat lavage fluids centrifuged at $55,000 \mathrm{~g}$ for $20 \mathrm{~min}$ (Coonrod, J. D., and M. Jarrells, unpublished data), indicating that this compartment needs to be studied to determine the total FFA content of different lavage fluids. Thus, the significance of differences in FFA content and antibacterial activity in vitro as far as host defenses in vivo is unknown.

The possibility that FFA in lavage are an artifact of the collection procedure, due perhaps to lipase activity of lavage constituents, cannot be excluded completely. On direct test with radiolabeled dipalmitoyl phosphatidylcholine or palmitoyl lysophosphatidylcholine added to the infusate, however, we could not detect release of FFA with lavage. Perhaps the best evidence that FFA in lavage are present in the alveoli in significant quantities comes from studies of alveolar macrophages. Resident alveolar macrophages of mice and rats maintained in "clean" conditions (under positive pressure ventilation) have few detectable complement receptors and display cell membrane abnormalities detectable by freeze-fracture microscopy suggestive of altered membrane fluidity $(51,52)$. In contrast, murine monocyte/macrophages freshly arrived in the alveolar space in response to inflammatory stimuli, or resident peritoneal macrophages of rats, have morphologically normal membranes and easily detectable complement receptors (51, 53, 54). Peritoneal macrophages incubated in the surfactant fraction of lavage develop reversible membrane abnormalities similar to those seen in rat resident alveolar macrophages (55). These findings suggest that the abnormalities of resident alveolar macrophage membranes are due to factors in the alveolar microenvironment. Recently, we showed that FFA are the factors in rat surfactant responsible for membrane abnormalities and diminished detectability of complement receptors of alveolar macrophages (Coonrod, J. D., and M. Jarrells, unpublished data). These observations indicate that the effects of FFA on both alveolar leukocytes and microorganisms must be considered in future studies of alveolar host defenses.

\section{Acknowledgments}

The authors thank James M. Lynch, Dr. Robert M. Simpson, and Dr. Dennis R. Voelker of National Jewish Hospital, Denver, for helpful discussions and Milford Jarrells and Steve Marple for technical assistance.

This work was supported by the Veterans Administration and by a grant from National Institutes of Health (1 R01 HL31565).

\section{References}

1. Green, G. M., and E. H. Kass. 1964. Factors influencing the clearance of bacteria by the lung. J. Clin. Invest. 43:769-776.

2. Green, G. M., and E. H. Kass. 1964. The role of the alveolar 
macrophage in the clearance of bacteria from the lung. J. Exp. Med. 119:167-175.

3. Goldstein, E., W. Lippert, and D. Warshauer. 1974. Pulmonary alveolar macrophage. Defender against bacterial infection of the lung J. Clin. Invest. 54:519-528.

4. Kim, M., E. Goldstein, J. P. Lewis, W. Lippert, and D. Warshauer. 1976. Murine pulmonary alveolar macrophage: rates of bacterial ingestion, inactivation, and destruction. J. Infect. Dis. 133:310320.

5. Dauber, J. H., and R. P. Daniele. 1978. Chemotactic activity of guinea pig alveolar macrophages. Am. Rev. Respir. Dis. 117:673-684.

6. Territo, M. C., and D. W. Golde. 1979. The function of human alveolar macrophages. Res. J. Reticuloendothel. Soc. 25:111-120.

7. Baughn, R. E., and P. F. Bonventre. 1975. Phagocytosis and intracellular killing of Staphlococcus aureus by normal mouse peritoneal macrophages. Infect. Immun. 12:346-352.

8. LaForce, F. M., W. J. Kelly, and G. L. Huber. 1973. Inactivation of staphylococci by alveolar macrophages with preliminary observations on the importance of alveolar lining material. Am. Rev. Respir. Dis. 108:784-790.

9. Juers, J. A., R. M. Rogers, J. B. McCurdy, and W. W. Cook. 1976. Enhancement of bactericidal capacity of alveolar macrophages by human alveolar lining material. J. Clin. Invest. 58:271-275.

10. Nugent, K. M., and E. L. Pesanti. 1982. Nonphagocytic clearance of Staphylococcus aureus from murine lungs. Infect. Immun. 36:1185-1191.

11. Rehm, S. R., and J. D. Coonrod. 1982. Rapid clearance of pneumococci from the lungs of decomplemented rats. Infect. Immun. 36:24-29.

12. Coonrod, J. D., and K. Yoneda. 1983. Detection and partial characterization of antibacterial factor(s) in alveolar lining material of rats. J. Clin. Invest. 71:129-141.

13. Coonrod, J. D., and K. Yoneda. 1981. Complement and opsonins in alveolar secretions and serum of rats with pneumonia due to Streptococcus pneumoniae. Rev. Infect. Dis. 3:310-322.

14. Bligh, E. G., and W. J. Dyer. 1959. A rapid method of total lipid extraction and purification. Can. J. Biochem. Physiol. 37:911917.

15. Metcalf, L. D., A. A. Schmidt, and J. R. Pelka. 1966. Rapid preparation of fatty acid esters from lipids for gas chromatographic analysis. Anal. Chem. 38:514-515.

16. Tomasz, A. 1974. The role of autolysins in cell death. Ann. NY Acad. Sci. 235:439-447.

17. Pfleger, R. C., and H. G. Thomas. 1971. Beagle dog pulmonary surfactant lipids: lipid composition of pulmonary tissue, exfoliated lining cells, and surfactant. Arch. Intern. Med. 127:863-873.

18. Finley, T. N., and A. J. Ladman. 1972. Low yield of pulmonary surfactants in cigarette smokers. N. Engl. J. Med. 286:223-227.

19. King, R. J., and J. A. Clements. 1972. Surface active materials from dog lung. II. Composition and physiologic correlations. Am. J. Physiol. 223:715-726.

20. Soltesz, L. V., and P. Mardh. 1977. The lytic effect of lysolecithin on acholeplasmas and mycoplasmas. Acta. Pathol. Microbiol. Scand. Sect. B. 85:255-261.

21. Mardh, P., and D. Taylor-Robinson. 1974. The susceptibility of aerobic and anaerobic bacteria, L-phase variants, candida, protozoa and viruses to lysolecithin. Acta. Pathol. Microbiol. Scand. Sect. B. 82:748-752.

22. Dubos, R. J. 1947. The effect of lipids and serum albumin on bacterial growth. J. Exp. Med. 85:9-22.
23. Nieman, C. 1954. Influence of trace amounts of fatty acids on the growth of microorganisms. Bacteriol. Rev. 18:147-162.

24. Kabara, J. J., D. M. Swieczkowski, A. J. Conley, and J. P. Truant. 1972. Fatty acids and derivatives as antimicrobial agents. Antimicrob. Agents Chemother. 2:23-28.

25. Larsson, K., B. Noren, and G. Odham. 1975. Antimicrobial effect of simple lipids with different branches at the methyl end group. Antimicrob. Agents Chemother. 8:742-750.

26. Heczko, P. B., R. Lutticken, W. Hryniewicz, M. Neugebauer, and G. Pulverer. 1979. Susceptibility of Staphylococcus aureus and Group A, B, C, and G streptococci to free fatty acids. J. Clin. Microbiol. 9:333-335.

27. Prince, H. N. 1959. Effect of pH on the antifungal activity of undecylenic acid and its calcium salt. J. Bacteriol. 78:788-791.

28. Wyss, O., B. J. Ludwig, and R. R. Joiner. 1945. The fungistatic and fungicidal action of fatty acids and related compounds. Arch. Biochem. 7:415-424.

29. Stock, C. C., and T. Francis, Jr. 1940. The inactivation of the virus of epidemic influenza by soaps. J. Exp. Med. 71:661-681.

30. Sands, J., D. Auperin, and W. Snipes. 1979. Extreme sensitivity of enveloped viruses, including herpes simplex, to long chain unsaturated monoglycerides and alcohols. Antimicrob. Agents Chemother. 15:6773.

31. Kohn, A., J. Gitelman, and M. Inbar. 1980. Unsaturated free fatty acids inactivate animal enveloped viruses. Arch. Virol. 66:301306.

32. Arnold, L., C. J. Gustafson, T. G. Hull, B. E. Montgomery, and C. Singer. 1930. The self-disinfecting power of the skin as a defense against microbic invasion. Am. J. Hygiene. 11:345-361.

33. Ricketts, C. R., J. R. Squire, and E. Topley. 1951. Human skin lipids with particular reference to the self-sterilizing power of the skin. Clin. Sci. 10:89-110.

34. Aly, R., H. I. Maibach, R. Rahman, H. R. Shinefield, and A. D. Mandel. 1975. Correlation of human in vivo and in vitro cutaneous antimicrobial factors. J. Infect. Dis. 131:579-583.

35. Aly, R., H. I. Maibach, H. R. Shinefield, and W. G. Strauss. 1972. Survival of pathogenic microorganisms on human skin. J. Invest. Dermatol. 58:205-210.

36. Fuller, R., and J. H. Moore. 1967. The inhibition of the growth of Clostridium welchii by lipids isolated from the contents of the small intestine of the pig. J. Gen. Microbiol. 46:23-41.

37. McFarland, L., T. A. Mietzner, J. S. Knapp, E. Sandstrom, K. K. Holmes, and S. A. Morse. 1983. Gonococcal sensitivity to fecal lipids can be mediated by an Mtr-independent mechanism. J. Clin. Microbiol. 18:121-127.

38. Michael, R. P., R. W. Bonsall, and P. Warner. 1974. Human vaginal secretions. Volatile fatty acid content. Science (Wash. DC). 186:1217-1219.

39. Goldman, A. S., and C. W. Smith. 1973. Host resistance factors in human milk. J. Pediatr. 82:1082-1090.

40. Dye, E. S., and F. A. Kapral. 1981. Characterization of a bactericidal lipid developing within staphylococcal abscesses. Infect. Immun. 32:98-104.

41. Miller, R. D., K. E. Brown, and S. A. Morse. 1977. Inhibitory action of fatty acids on the growth of Neisseria gonorrheae. Infect. Immun. 17:303-312.

42. Kabara, J. J., R. Vrable, and M. S. F. Lie Ken Jie. 1977 Antimicrobial lipids: natural and synthetic fatty acids and monoglycerides. Lipids. 12:753-759.

43. Fay, J. P., and R. N. Farias. 1975. The inhibitory action of 
fatty acids on the growth of Escherichia coli. J. Gen. Microbiol. 91:233-240.

44. Galbraith, H., T. B. Miller, A. M. Paton, and J. K. Thompson. 1971. Antibacterial activity of long chain fatty acids and the reversal with calcium, magnesium, ergocalciferol, and cholesterol. J. Appl. Bacteriol. 34:803-813.

45. Sheu, C. W., and E. Freese. 1973. Lipopolysaccharide layer protection of gram-negative bacteria against inhibition by long-chain fatty acids. J. Bacteriol. 115:869-875.

46. Galbraith, H., and T. B. Miller. 1973. Physiochemical effects of long chain fatty acids on bacterial cells and their protoplasts. $J$. Appl. Bacteriol. 36:647-658.

47. Davis, M.-T. B., and D. F. Silbert. 1974. Changes in cell permeability following a marked reduction of saturated fatty acid content of Escherichia coli K-12. Biochim. Biophys. Acta. 373:224241.

48. Sheu, C. W., W. N. Konings, and E. Freese. 1972. Effects of acetate and other short chain fatty acids on sugar and amino acid uptake of Bacillus subtilis. J. Bacteriol. 111:525-530.
49. Ingram, L. O., L. C. Eaton, G. W. Erdos, T. F. Tedder, and N. L. Vreeland. 1982. Unsaturated fatty acid requirement in Escherichis coli. Mechanism of palmitate-induced inhibition of growth by strain WN1. J. Membr. Biol. 65:31-40.

50. Fay, J. P., and R. N. Farias. 1977. Inhibitory action of a nonmetabolizable fatty acid on the growth of Escherichia coli. Role of metabolism and outer membrane integrity. J. Bacteriol. 132:790-795.

51. Coonrod, J. D., and S. R. Rehm. 1982. Complement receptors of rat alveolar macrophages. J. Reticuloendothel. Soc. 31:107-115.

52. Van Oud Alblas, A. B., and R. Van Furth. 1979. Origin, kinetics and characteristics of pulmonary macrophages in the normal steady state. J. Exp. Med. 149:1504-1518.

53. Warr, G. A., G. J. Jakab, and J. E. Hearst. 1979. Alterations in lung macrophages immune receptor(s) activity associated with viral pneumonia. J. Reticuloendothel. Soc. 26:357-366.

54. Harmsen, A. G., and E. L. Jeska. 1980. Surface receptors of procine alveolar macrophages and their role in phagocytosis. J. Reticuloendothel. Soc. 27:631-637.

55. Coonrod, J. D., and K. Yoneda. 1983. Effect of rat alveolar lining material on macrophage receptors. J. Immunol. 130:2589-2596. 